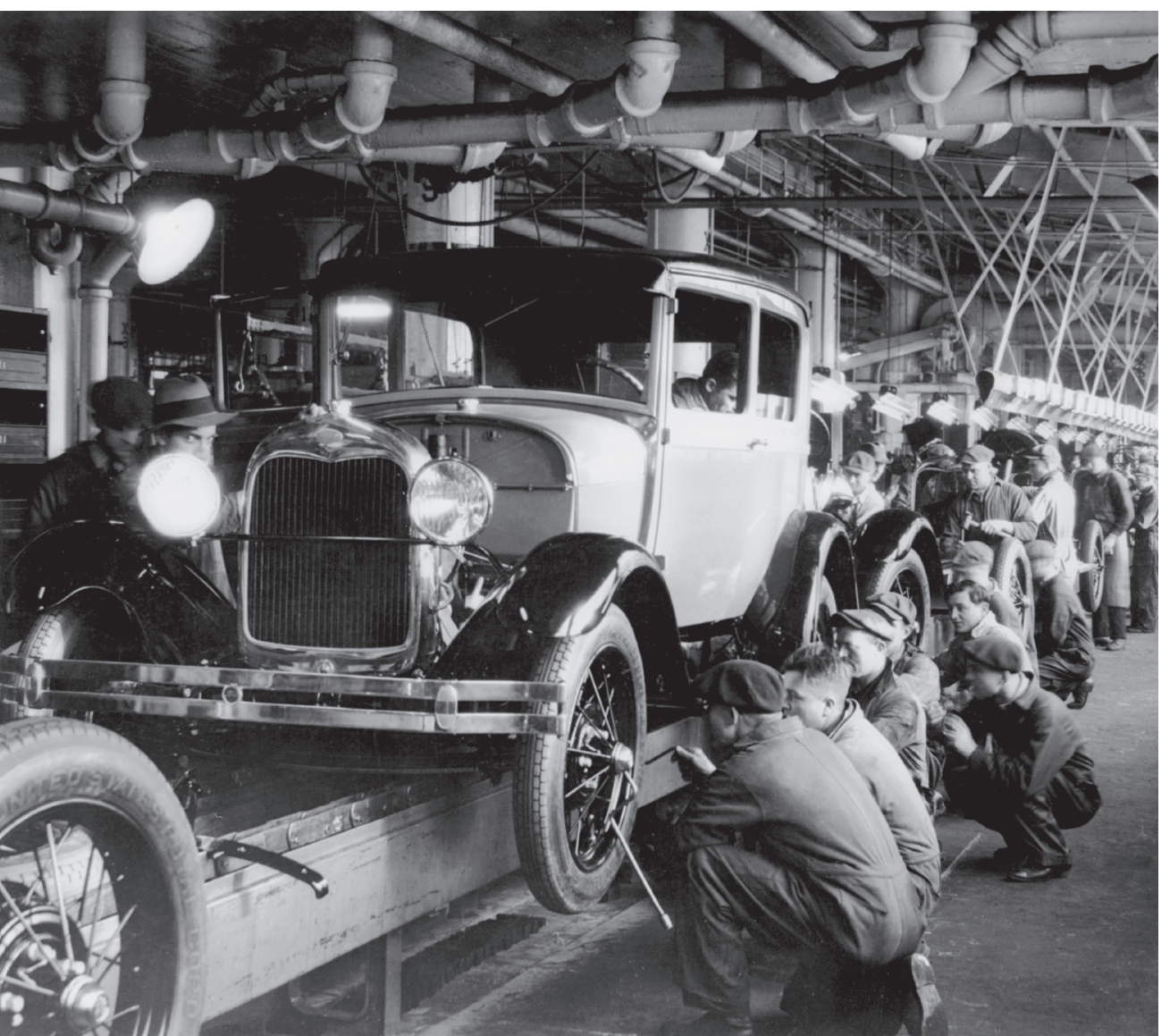

Ford cars under construction in Michigan in 1927.

\title{
AUTOMOBILE TECHNOLOGY
}

\section{Driven to distraction}

\section{Jack Stilgoe applauds a timely and alarming chronicle of the history of US road safety.}

\section{$\mathrm{T}$} he story told by countless advertisements is that cars mean freedom - open roads, high speeds and boundless possibilities. The paradox is that, when we drive, we are perhaps more constrained than in any other area of everyday life. The German philosopher Max Horkheimer wrote in 1947, "It is as if the innumerable laws, regulations and directions with which we must comply were driving the car, not we."

The shape of a car, the behaviour of a driver, the design of a traffic light and ultimately the configuration of a city are products not just of industrial ingenuity, but of an unfinished tussle between companies and regulators. Many of the rules and standards embodied in car design aim to keep us safe. Yet being in or around cars is among the most dangerous things we do. Some 1.35 million people die on the world's roads every year. Developers of autonomous vehicles think this problem can be solved through artificial

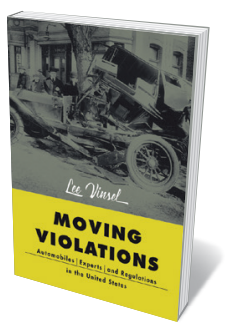

Moving Violations: Automobiles, Experts, and

Regulations in the United States

LEE VINSEL

John Hopkins

University Press (2019) \section{Handmade by busi-} nesses such as the Duryea Motor Wagon Company, these automobiles were playthings of the rich. And risk was part of the appeal. It quickly became clear that a privileged few were creating a public menace. A chaotic aftermarket of safety widg ets offered drivers protection in what were then low-speed crashes; but more than 1,000 people were killed by motor vehicles in the United States in 1909. A year before that, the arrival of the Ford Model T made cars affordable for the middle classes, and by 1913 more than one million cars were registered. Safety became a major concern.

For Henry Ford's mass production to work, it required standardization. Screws had to fit regardless of which factory they came from. And this was part of a bigger story - the standardization of streets, traffic signals, drivers and pedestrians. Road safety started to be acknowledged as a problem but, in their battle with government, carmakers found it easy to offload responsibility onto others. John O'Brien, the inspector in charge of traffic for the New York City Police Department in the 1920 s, explained that the priority was to "educate the pedestrians". However, through the concerted action of the insurance industry, regulators and researchers in organizations such as the Society of Automotive Engineers (founded in 1905), carmakers were persuaded that safer cars would be good for their bottom line. From the 1930 s to the 1960 s, the US road death toll climbed, but more slowly than the number of kilometres travelled. (It peaked at more than 50,000 deaths a year in the mid-1970s, then slowly declined.)

\section{RESEARCH ROAD MAP}

As Vinsel shows, a history of science is woven through this regulatory tale. Researchers funded by public bodies such as what is now the US National Academies of Sciences, Engineering, and Medicine were confident that they could control risk through scientific knowledge. Psychologists at the National Research Council attempted to work out why some people were more "accident-prone" than others, and how driving tests and lessons could compensate for human failings. Some engineers - including former pilot Hugh DeHaven at Cornell University in Ithaca, New York — admitted that accidents were inevitable. They created the science of crashworthiness in the 1930s and 1940s. Here, the details become grisly. Experiments to work out how car design could protect human bodies began with dropping eggs from different heights and led to tests on live dogs and human cadavers (by the early 2000s, clad in "Smurf-blue leotards" to keep their extremities together after impact).

In the mid-twentieth century, the debate about road safety became more technocratic and lost some of its passion. It was reawakened in the 1960s by campaigners such as consumer advocate Ralph Nader, whose reputation was enhanced by the industry's 
attempts to discredit him. Nader blended scientific evidence with political nous to argue that carmakers' disregard for safety was unjust as well as unwise. And under presidents Lyndon B. Johnson and Richard Nixon, the government began to assert itself on both car safety and environmental pollution. Manufacturers would no longer be able to add safety features just as a luxury. They were forced to develop technologies such as crumple zones to absorb impacts, and catalytic converters to meet tough laws imposed by the Environmental Protection Agency in the 1970s. Vinsel points out that the 2015 scandal in which Volkswagen admitted it had cheated on emissions tests has plenty of precedents from this period.

Vinsel's argument is that regulation involves the definition of problems. Scientific knowledge alone will not force action, and engineers need to be told what to focus on. In the history

"Road safety started to be acknowledged as a problem but carmakers found it easy to offload responsibility." of car safety, problems have mostly been defined by carmakers, who have prioritized comfort over safety. Where they have focused on safety, the trade-offs have been problematic.

The now-ubiquitous sports utility vehicle (SUV) - safer for drivers, but more likely to kill pedestrians - is a product of this view, and also a cautionary tale of unintended consequences. It was designed to be classed as a truck, and therefore exempt from emissions controls.

Vinsel wants to be optimistic. He sees his story as a case of government regulation steering technologies in a positive direction. His book, however, is entirely UScentric, even though the market for cars is global and technological standards have been exported and imported. His argument could have been more powerful with some international comparisons.

The US record on road safety remains woeful; the death rates per kilometre in Sweden and Britain are less than half those in the United States. Self-driving cars look like a poor technological fix for this problem. At a time when tech companies including Facebook, Uber and Google are given a free rein by US regulators and the specious promises of self-driving cars are used to justify further deregulation, a defence of government's role in technological development is much needed.

Jack Stilgoe is an associate professor of science and technology studies at University College London. His forthcoming book Who's Driving? will be published by Palgrave Macmillan.

e-mail:j.stilgoe@ucl.ac.uk

\section{Books in brief}

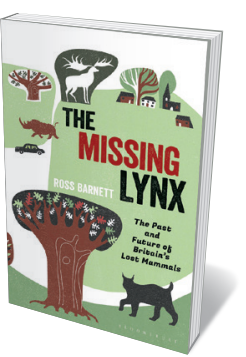

The Missing Lynx

Ross Barnett BLOOMSBURY (2019)

The story of life on Earth is a saga of extinction, declares palaeontologist Ross Barnett in this fresh and assured natural history of departed megafauna. Arguing that human 'overkill' was (with climate change) a major driver long before our population exploded in the Holocene epoch, Barnett uses Britain as a microcosm of the planetary record. Here are long-gone species such as the cave hyena (Crocuta crocuta spelaean), the fearsome scimitar-toothed cat (Homotherium latidens) and the northern lynx (Lynx lynx lynx); thrilling tales of discovery; and the vagaries of reintroduction. An often moving tribute to lost marvels.

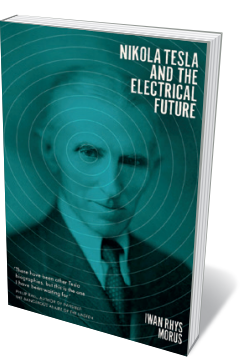

Nikola Tesla and the Electrical Future Iwan Rhys Morus ICON (2019)

The Serbian inventor and electrical engineer Nikola Tesla seems to many uncannily prescient. Yet the scientist - by turns reclusive and flamboyant - was very much a product of the late nineteenth century. Historian Iwan Rhys Morus examines the man through that lens: a time of rampant entrepreneurialism, bravura innovations, grandiose visions of techno-utopia and futuristic science fiction. His crisply succinct, beautifully synthesized study brings to life Tesla, his achievements and failures (such as interplanetary communication), and the hopeful thrum of an era before world wars.

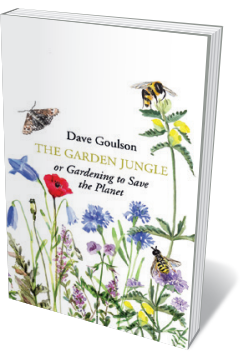

The Garden Jungle

Dave Goulson JONATHAN CAPE (2019)

Woodlice, earthworms, earwigs: a seething Serengeti lurks in many a back garden. Apiologist Dave Goulson's wonderful book encourages such richness by delivering solid science on garden wilding. Calling out today's cocktail of industrial pesticides as extreme in residential settings, he shows how robust plants and natural predators such as lacewings do the job sustainably. He extols the delights of eating roadkill, shows how to craft hoverfly habitats and advocates growing heritage crop varieties. Above all, Goulson demonstrates that the domestic nature reserve is the first step towards saving the planet.

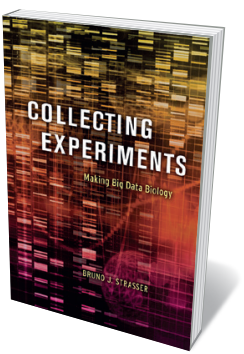

Collecting Experiments

Bruno Strasser UNIVERSITY OF CHICAGO PRESS (2019)

We often think of big data as an explosive departure from the past. Science historian Bruno Strasser reveals it as part of a historic continuum. The sense of 'information overload' has existed since the Renaissance, and today's data tsunami emerged from two traditions in biology: natural-history collecting and the lab. Hybridized, they led to vast accumulations of knowledge. Strasser's case studies compel, from geneticists' 'museums' of maize (corn) varieties to a groundbreaking mine of digital data, the 1965 Atlas of Protein Structure and Sequence, coproduced by bioinformatics pioneer Margaret Dayhoff.

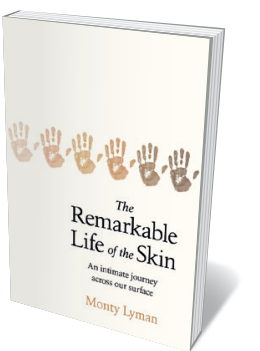

\section{The Remarkable Life of the Skin}

Monty Lyman BANTAM (2019)

Physician Monty Lyman peels back the science on human skin in this absorbing, fact-packed study. Dubbing it the "Swiss Army knife" of organs, Lyman examines skin as a barrier against trauma, a carrier of microbes, a matrix for nerve endings and a screen for the emotions. He reveals that structurally it is an "ideal foam", explores skin-gut communication, looks at medicinal tattooing and muses over ritual cleansing. Skin, he shows, is a thing of both surface and depth, a very visible yet personal part of ourselves that can become a target, too, of egregious attacks against difference. Barbara Kiser 